\title{
Surgical Pulmonary Embolectomy Outcomes for Acute Pulmonary Embolism
}

\author{
Nicholas D. D'Antonio \\ Thomas Jefferson University, nicholas.d'antonio@jefferson.edu \\ Jae Hwan Choi, MD \\ Thomas Jefferson University, jae.choi2@jefferson.edu \\ Thomas J. O'Malley, MD \\ Thomas Jefferson University, thomas.o'malley2@jefferson.edu \\ Elizabeth J. Maynes, MD \\ Thomas Jefferson University, elizabeth.maynes@jefferson.edu \\ Follow this and additional works at: https://jdc.jefferson.edu/si_ctr_2022_phase1 \\ natthew P. Weber, MS

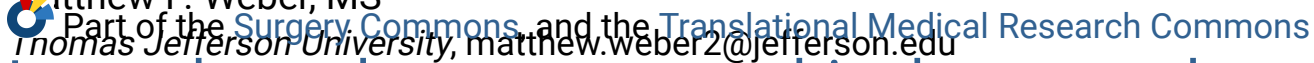 \\ Let us know how access to this document benefits you
}

\section{See next page for additional authors}

Recommended Citation

D'Antonio, Nicholas D.; Choi, MD, Jae Hwan; O'Malley, MD, Thomas J.; Maynes, MD, Elizabeth J.;

Weber, MS, Matthew P.; Mellado, MD, Martín; West, MD, Frances M.; Galanis, MD, Taki;

Gonsalves, MD, Carin F.; Marhefka, MD, Gregary D.; Awsare, MD, Bharat K.; Merli, MD, Geno J.; and Tchantchaleishvili, MD, Vakhtang, "Surgical Pulmonary Embolectomy Outcomes for Acute Pulmonary Embolism" (2020). Phase 1. Paper 80.

https://jdc.jefferson.edu/si_ctr_2022_phase1/80

This Article is brought to you for free and open access by the Jefferson Digital Commons. The Jefferson Digital Commons is a service of Thomas Jefferson University's Center for Teaching and Learning (CTL). The Commons is a showcase for Jefferson books and journals, peer-reviewed scholarly publications, unique historical collections from the University archives, and teaching tools. The Jefferson Digital Commons allows researchers and interested readers anywhere in the world to learn about and keep up to date with Jefferson scholarship. This article has been accepted for inclusion in Phase 1 by an authorized administrator of the Jefferson Digital Commons. For more information, please contact: JeffersonDigitalCommons@jefferson.edu. 


\section{Authors}

Nicholas D. D'Antonio; Jae Hwan Choi, MD; Thomas J. O'Malley, MD; Elizabeth J. Maynes, MD; Matthew P. Weber, MS; Martín Mellado, MD; Frances M. West, MD; Taki Galanis, MD; Carin F. Gonsalves, MD; Gregary

D. Marhefka, MD; Bharat K. Awsare, MD; Geno J. Merli, MD; and Vakhtang Tchantchaleishvili, MD 


\title{
Surgical Pulmonary Embolectomy Outcomes for Acute Pulmonary Embolism
}

\author{
Jae Hwan Choi MD, Thomas J. O'Malley MD, Elizabeth J. Maynes MD, Matthew P.
}

Weber MS, Nicholas D. D'Antonio BS, Martín Mellado MD, Frances M. West MD,

Taki Galanis MD, Carin F. Gonsalves MD, Gregary D. Marhefka MD, Bharat K.

Awsare MD, Geno J. Merli MD, Vakhtang Tchantchaleishvili MD*

$\left(^{*}\right)$ indicates primary project advisor

Introduction: Acute pulmonary embolism (PE) is associated with significant mortality. Surgical embolectomy is a viable treatment option; however, it remains controversial due to variable outcomes. This review investigates patient outcomes following surgical embolectomy for acute PE.

Methods: Electronic search was performed to identify articles reporting surgical embolectomy for treatment of PE. 32 studies were included comprising 936 patients. Demographic, perioperative, and outcome data were extracted and pooled for systematic review.

Results: Mean patient age was 56.3 [95\% $\mathrm{Cl} 52.5 ; 60.1]$ years and $50 \%$ [46; 55] were male. $82 \%$ had right ventricular dysfunction [62; 93], 80\% [67; 89] had unstable hemodynamics, and 9\% [5; 16] experienced cardiac arrest. Massive PE and submassive PE were present in $83 \%$ of patients [43; 97] and $13 \%$ [2; 56], respectively. Before embolectomy, $33 \%$ of patients $[14 ; 60]$ underwent systemic thrombolysis and $14 \%$ [8; 24] catheter embolectomy. Preoperatively, $47 \%$ of patients were ventilated [26; 70 ] and $36 \%$ had percutaneous cardiopulmonary support [11; 71]. Mean operative time and mean cardiopulmonary bypass time were $170[101 ; 239]$ and $56[42 ; 70]$ minutes, respectively. Intraoperative mortality was 4\% [2; 8]. Mean hospital and ICU stay were 10 $[6 ; 14]$ and $2[1 ; 3]$ days, respectively. Mean postoperative systolic pulmonary artery pressure (SPAP) was significantly decreased from preoperative (sPAP $57.8 \mathrm{mmHg}$ [53; 62.7]) to postoperative period (sPAP $31.3 \mathrm{mmHg}$ [24.9; 37.8]), $\mathrm{p}<0.01$ ). In-hospital mortality was $16 \%$ [12; 21]. Overall survival at five years was $73 \%$ [64; 81$]$.

Discussion: Surgical embolectomy is an acceptable treatment option with favorable outcomes. 